\title{
South Africans inured to death
}

\begin{abstract}
Death cafés - the concept sounds ghoulish, but they could soon become as much a reality in South Africa (SA) as they are in North America, Europe and Australia. This follows a groundbreaking local judgment that has the best legal and medical minds debating whether euthanasia can ever be justified in this country.

Tea, cake and a cosy chat about our demise is not somebody's idea of dark humour. It's a sincere and very smart attempt to destigmatise the thing many of us fear the most. By getting together to chat about our mortality and hopefully normalise death as a part of life, we'll hopefully be able to shuffle off this mortal coil with more peace of mind than if we ignored the issue completely. The café concept, while sounding more like dark comedic science fiction (e.g. 'The Restaurant at the End of the Universe' by Douglas Adams), could perhaps more accurately be dubbed 'The Café about the End of my Life'. The approach, initiated by the worldwide palliative care community, is that, like it or not, we'll have to make pragmatic decisions about our demise sometime, so why not sooner than later - and in a congenial environment? The recent groundbreaking judgment that legalised (albeit just hours after his natural death) assisted suicide for Cape Town advocate Robin StranshamFord, and described the relevant outdated law as unconstitutional, has evoked huge public interest about a host of end-of-life issues. Discussion, in death cafés or not, has turned to whether and/or under what circumstances we should be able to end our lives (or have somebody help us die).
\end{abstract}

\section{'We're in denial' - hospice chief}

Most of us are in denial about death, says Dr Liz Gwyther, President of the International Hospice and Palliative Care Association (and CEO of the SA equivalent). She believes that both the Stransham-Ford court application and much of the current discussion and debate are driven by our own personal fears and imaginings of how we might die. 'We don't ever know how the situation is going to be until we are actually living it. Often our fears and imaginings are a lot worse than reality. Perhaps the most powerful underpinning of her contention (and support for death cafés) is that pain - with all its concomitant maladies of depression, indignity, hopelessness and lack of control - is today eminently manageable using opioids (mainly morphine). So much so that death can be peaceful and lucid, with any pain well controlled. Once the body has adjusted to the morphine ( $3-7$ days), full

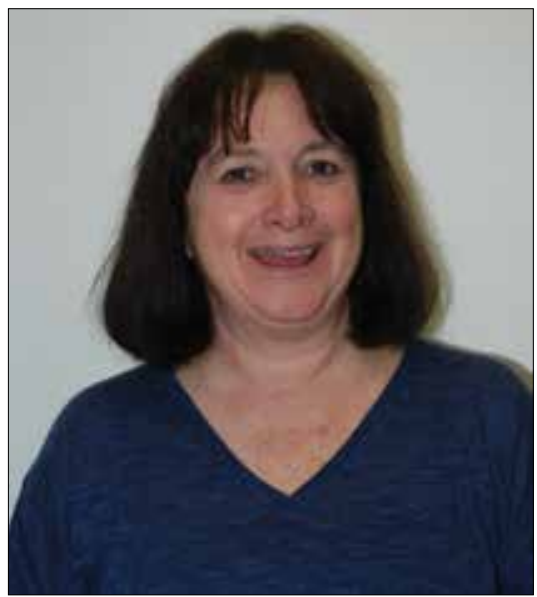

Dr Liz Gwyther, President of the International Hospice and Palliative Care Association.

lucidity returns. Gwyther has seen hundreds of people die in her 23 years of palliative care and believes that death is an opportunity and process in which there can be 'a lot of living, richness, incredible growth and family interaction. She also emphasises that euthanasia is a one-way street with no possibility of return. Research has shown overwhelming relief and gratitude by those people whove contemplated it in a moment of despair, but chose holistic palliation. Talk to any severely disabled person who has had to come to terms with their condition, she adds, and they'll tell you how close they were to 'ending it all' - and how far the emotional pendulum can swing. Euthanasia is an anathema to palliative care practice internationally, 'an unnecessarily extreme measure', because physical, emotional, psychological and spiritual pain can be addressed, using extrinsic and intrinsic resources, the latter drawing on skills and successful coping mechanisms acquired during previous life crises. Palliative care could control confusion, and people who were well supported with palliative care and experienced alleviation of symptoms could become less afraid. Stransham-Ford had expressed the fear that 'his last breath might be with the aid of a machine. Gwyther said it was recognised that a person could refuse treatment and, in this case, refuse respiratory support, which was inappropriate treatment' for a person with a short prognosis. The essence of palliative care was the relief of suffering, she stressed. Stransham-Ford had also feared dying while suffering, yet an experience of palliative care would have allayed that fear. Gwyther said palliative care neither hastened nor postponed death, most powerfully citing former President Nelson Mandela's 'politically managed' 6-month, drawn-out death in which he finally succumbed after being put on life support in hospital.

\section{Madiba's end 'cynically manipulated'}

Both Gwyther and her euthanasia opponent, Prof. Willem Landman of Dignity South Africa (a pro-euthanasia human rights group), believe that Mandela's drawn-out passing was politically motivated. Gwyther says Mandela was 'denied the comfort of the old man's friend' - a natural and peaceful death from pneumonia. Landman is more forthright. He says that, had Mandela been capable, "he would have thought the last 6 months of his life an assault on his dignity, orchestrated by a manipulative and self-interested government'. Landman, Executive Director of the Ethics Institute of South Africa, spoke alongside Gwyther and several other top academics at a Wits University 'Reflections on End-of-Life Decisions' public debate at the Steve Biko Centre for Bioethics on 14 May (soon after the Stransham-Ford judgment). Landman was scathing about comments attributed to health minister Dr Aaron Motsoaledi, saying he had 'no business giving his 'purely personal interpretations of constitutional rights without engaging with authoritative sources.' The judgment by Judge H J Fabricius of the North Gauteng High Court included a recommendation that the law should be 'developed' to bring it more in line with 1998 recommendations by the SA Law Commission (SALC) favouring the sanctity of a dignified death and assisted dying and avoiding the current clash with the Bill of Rights. Landman said the government response to the ruling 'demeans public debate', and accused it of being 'on a crusade'

\section{Government should 'accept the Constitution'} Government should instead 'unambiguously accept the Constitution as the highest authority and uplift public debate' Both Landman and Prof. David McQuoidMason, Director of the Centre for SocioLegal Studies at the University of KwaZuluNatal, agree that the judgment opens the way for the Constitutional Court to endorse the SALC's recommended changes on existing euthanasia law - and that it enables anyone to bring a similar application to the High Court, which would then treat each case on its merits. Landman said Judge Fabricius clearly thought that doctor-assisted suicide was 'a matter of great public importance' and declined the government's request to throw out the case because the patient had died shortly before he delivered it. Landman argues that public policy should be developed 


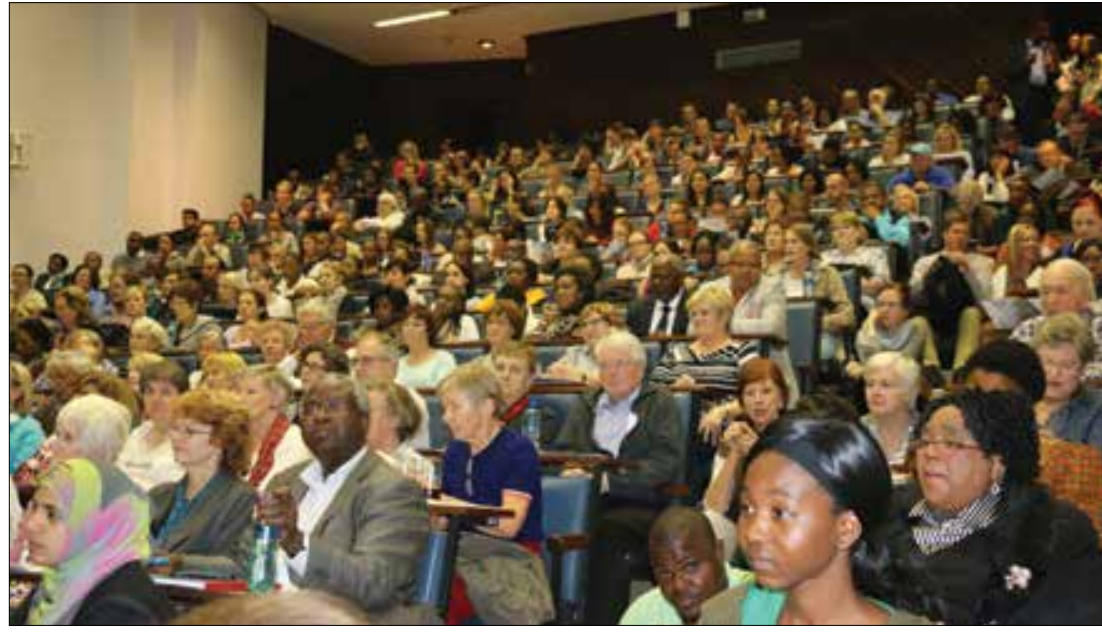

A capacity audience reflected on end-of-life decisions at the Wits Steve Biko Centre for Bioethics on 14 May.

on the basis of the spirit, values and rights of the Constitution, not personal, religious or cultural beliefs. Dignity SA, which supported Stransham-Ford's court application, believes in the fundamental ethical values of respect for life and freedom of choice, as well as the virtues of compassion and solidarity with those who suffer. Landman said that as the law stood, the Constitutional rights to dignity and freedom to bodily and psychological integrity were being denied. The draft legislation in the SALC report had been 'callously ignored' by Parliament for 17 years, with one of the Stransham-Ford court respondents, the Department of Justice and Correctional Services, saying it had 'not the remotest intention' of tabling new legislation. Among the serious disagreements in the public debate were balancing the right to dignity and the right to life, the legitimate limits of a medical practitioner's professional duties, whether suicide should be a purely personal matter, possible abuse of vulnerable persons, access by the poor, the effectiveness of safeguards, the limits of palliative care and the relevance of 'God's will' and cultural beliefs in constitutional interpretation.

\section{'It is harder morally to justify} letting somebody die a slow and ugly death dehumanised, than it is to justify helping to avoid it.' (J M T Labuschagne ${ }^{[1]}$ )

\section{Whose God decides?}

Observed Landman: 'Assuming God exists and communicates with us, how does one resolve conflicting understandings of his will? Which religion, which interpretation of a specific religion?' he prodded. Good medicine already 'played God' in many other ways, thereby manipulating the time and manner of death (e.g. surgery, antibiotics, intervening in the dying process). Landman rebutted Motsoaledi's arguments that doctors were 'not to be looked upon as people who kill', that they 'can kill anytime but don't, because not killing is imbedded in their minds' and that doctors should provide palliative care to enable death with dignity. He said Motsoaledi's concern was 'misplaced' given the country's dysfunctional public hospitals where unnecessary deaths were commonplace and palliative care grossly inadequate. Gwyther says that $4 \%$ of South Africans who would clinically qualify for palliative care are getting it and that only 10 hospitals in SA have a palliative care service. Lack of funding has meant that the number of hospices dropped from 202 in 2011 to 153 currently. However, partnerships had been developed between these hospices and 400 state facilities while training and expansion was ongoing, she added.

\section{Doctors have 'special moral duties'}

Landman told the Wits symposium that doctors had 'special moral duties' when death was 'inevitable, and suffering intractable and unbearable. He said there was also no intrinsic moral difference between assisted dying and standard-of-care practices such as withholding or withdrawing treatment or pain management that shortened life. While palliative care was 'non-negotiable', it was limited by freedom of choice. It was not for the state to say 'we should choose other options (such as palliative care), since we have a constitutional right to dignity, and dignity encompasses one's own conception of how to cease to live'. A patient might also not want terminal sedation, which may be the only relief from pain. He described the health minister's argument that any legalising of assisted dying would create a potential rise in fraud and unethical behaviour among doctors as 'dim, alarmist and insulting to doctors and families as closet killers, and dying patients as fraudulent schemers'.

\section{SA 'not a safe and appropriate place' for euthanasia}

Prof. Dan Ncayiyana, Editor Emeritus of the $S A M J$, said the justification for active euthanasia or physician-assisted suicide was 'compelling - all things considered equal and in the right context'. However, SA was 'not a safe and appropriate place' for legalised euthanasia 'at this time'. Current inequalities would benefit the well-off, while opening up the potential for perverse application among the burgeoning poor population and other vulnerable groups. The public health system was 'broken and decrepit' with little respect for human life, making a default to euthanasia likely. 'In SA there is no respect for human life, with 45 murders per day, mob-justice and police killings. There are needless hospital deaths and neglect and indifference in them. Healthcare workers easily down tools, regardless of the cost in human life and suffering, he added. Legalised euthanasia needed 'a functional and reliable framework of supervision to monitor implementation'. SA had a 'dismal record and reputation, certainly in the health and medical landscape,' he said, citing the recently probed dysfunctional Health Professions Council of South Africa.

\section{'My problem with euthanasia is not that it is an immoral way to die, but that it has its roots in a fearful way to live.' (Gwyther, quoting Fraser ${ }^{[2]}$ )}

'From a public policy point of view, for the state to sanction the deliberate taking away of a life would send the wrong message,' Ncayiyana said, concluding that the time was 'not yet ripe' for legally sanctioned active euthanasia. He quoted a scholar on the decriminalisation of euthanasia, Prof. J M T Labuschagne, as saying: 'It is harder morally to justify letting somebody die a slow and ugly death dehumanised, than it is to justify helping to avoid it.'

Gwyther welcomed the current debate, saying that her Hospice and Palliative Care Association was 'already challenging 
our hospital managers, asking if they're ready to cope with even more requests [for palliative care] if they come'. Research by the South African Medical Research Council (Burden of Disease Unit statistics) had shown that 258268 people who could have benefited from palliative care died in 2010 . Her association managed to care for just
94585 of them. She believes that because of the global move towards safeguarded euthanasia, SA society will choose to allow the right to die, 'but a lot of people have responded by saying that if you have the right to die, there has to be a law around palliative care. We need equity of access to palliative care.'

\section{Chris Bateman}

chrisb@hmpg.co.za

1. Labuschagne JMT. Decriminalisasie van eutanasie. Tydskrif $\mathrm{v}$ Hedendaagse Romeins-Hollandse Reg (THRHR) 1998:176 (as cited in the SA Law Commission).

2. Fraser G. 'Loose Cannon' column, The Guardian, 13 May 2013.

S Afr Med J 2015;105(7):522-524.

DOI:10.7196/SAMJnew.7835 